\title{
ABBREVIATIONS OF THE NAMES OF MOST OF THE JOURNALS TO WHICH REFERENCE HAS BEEN MADE
}

Ann. Chem. . Liebig's Annalen der Chemie und Pharmacie (begun 1832).

Ann. Chim. . Annales de Chimie et de Physique (begun 1816; five series).

Ann. de Chimit . The same journal from 1789 to 1815.

Ann. des Mints. Annales des Mines.

Ann. of Philosophy Annals of Philosophy (edited by Thomas Thomson, 1813-26). This journal was subsequently mergeri in the Philosophical Mayasine.

Ann. Phys. . . The new Series (Neue Folge) of Poggendorff's Annalen. Archiv. Pharm. . Archiv der Pharmacie (begun 1832).

Bayer. Akad. . . Sitzungsberichte der Bayerischen Akademie der Wiss. enschaften.

Ber. . . . . . Berichte der Deutschen chemischen Gesellschaft (begun 1868).

Bull. Soc. Chim. . Bulletin de la Société Chimique de Paris (begun 1864).

Chem. Centr. . . Chemisches Centralblatt (begun 1848).

Chem. News . . Chemical News (begun 1860).

Compt. Rend. . . Comptes Rendus des Séances de l'Académie des Sciences (begun 1835).

Crell's Ann. . . Chemische Annalen von L. v. Crell (1784-1805).

Dingl. Jouru. . . Dingler's Polytechnisches Journal (begun 1820).

Gazz. Chim. Ital. . Gazzetta Chimica Italiana (begun 1871).

Gilb. Ann. . . . Annalen der Physik von Gilbert und Gren (1798-1824).

(Bericht über die Entwickelung der Chemischen Indus-

Hofmann's trie während des letzten Jahrzehnts von Hofmann Bericht, etc. . (began 1875, but ceased after the publication of two volumes).

Jahres. Berz. . . Jahresberichte über die Fortschritte der Chemie und Mineralogie von Berzelius (1821-47).

Jahres. d. Chemie Jahresberichte über die Fortschritte der Chemie von Liebig und anderen (begun 1847). 
Journ. Chem. Ind. Journal of the Society of Chemical Industry (begun 1882).

Journ. Chem. Soc. Journal of the Chemical Society (Memoirs and Proceedings, vols. i. -iii., 1841-47; Journal begun 1848).

Journ. de Phys. . Journal de Physique (1778-94; 1798-1823).

Journ. pr. Chem. Journal für praktische Chemie (begun 1834; the new series begun 1870).

Mon. Scient. . . Moniteur Scientifique (edited by Quesneville, begun 1857).

Phil. Mag. . Philosophical Magazine (hegun 1798).

Phil. Trans. . . Philosophical Transactions of the Royal Society (begun 1666).

Phil. Trans. E. . Philosophical Transactions of the Royal Society of Edinburgh (begun 1788).

Pogg. Ann. . . Annalen der Physik und Chemie von Poggendorff (begun 1824 ; new series begun 1877).

Proc. R. S. . . Proceedings of the Royal Society [begun 1800 . Vols. i. - iv. (1800-1843) are entitled "Abstracts of the Papers printed in the Philosophical Transactions of the Royal Society of London," and vols. v., vi. (1843-1854) "Abstracts of Papers communicated to the Royal Society." The final form of title, "Proceedings of the Royal Society of London," begins with vol. vii., published in 1856].

Proc. R. S. E. . Proceedings of the Royal Society of Edinburgh (begun 1845).

Rec. Trav. Chim. . Recueil des Travaux Chimiques (begun 1882).

Schweigg. Journ. Journal für Chemie und Physik von Schweigger (1811-33).

Wagner's Jahresber. Jahresbericht über die Leistungen der chemischen Technologie von Wagner (begun 1856).

Wiener Monatshefte Monatshefte für Chemie und verwandte Theile anderer Wissenschaften (begun 1880).

Ztschr. anal. Chem. Zeitschrift für analytische Chemie von Fresenius (begun 1862).

Ztschr. Chem. . Zeitschrift für Chemie (1865-71); this was a continuation of the Kritische Zeitschrift (begun 1858).

$Z t s c h r$. phys. Chem. Zeitschrift für physikalische Chemie, Stöchiometrie, und Verwandtschaftslehre (edited by Ostwald and van 't Hoff ; begun 1887). 


\section{ERRATA.}

Page 27, line 18, from top, for "Synesius" read "Synesios."

, 357, , 2, from top, for "Lebel " read " Le Bel."

" 386, ,, 2, from top, for " Kirchoff" read " Kirchhoff."

, 407, , 19, from top, for " Matthiessen " read "Mathiessen."

" 446, ,, 17, from top, for " R. Hofmann " read " R. Hoffmann."

, 481, ," 5, from foot, for "Huisberg" read "Hinsberg."

, 499, , 5, from foot, for " Lebel" read " Le Bel."

, 502, ,, 11, from foot, for " Eykman " read " Eykmann."

, 505, ,, 11, from foot, for "Scherer" read "Scheerer."

, 537, , 7, from top, for " formic acid " read " formic aldehyde."

, 543, ,, 11, from foot for "Scherer" read " Scheerer."

, 558, ,, 7, from foot, for " Pattison" read "Pattinson."

",575, note 4, for "Schüzenbach" read " Schützenbach." 